\title{
Effect of Stir Casting Process Parameters on Mechanical Properties of Aluminium Matrix Composites: Experimental Investigation and Predictive Modelling
}

\author{
Manu Khare, Ravi Kant Gupta \\ Manipal University Jaipur, Jaipur, Rajasthan, India
}

(Received 10 January 2021; revised manuscript received 24 March 2021; published online 09 April 2021)

\begin{abstract}
ANN (Artificial Neural Network) approach is used in this paper to model the complex nature of composites which have non-linear relationship with process parameters which effect their properties. The experiments were performed with different controlled input parameters like melting temperature, percentage reinforcement and die temperature on the mechanical performance of aluminium matrix composites fabricated through stir casting. Levenberg-Marquardt algorithm was employed to predict the properties of the composites. The work confirms that Neural Network learned by Levenberg-Marquardt Algorithm (NNLMA) is a reliable method with high level of accuracy to predict the mechanical properties of the composites fabricated using stir casting.
\end{abstract}

Keywords: Composite materials, Ceramic reinforcement, $\mathrm{Al}_{2} \mathrm{O}_{3}, \mathrm{~B}_{4} \mathrm{C}$, Carbon black, ANN, Mathematical modelling.

DOI: 10.21272/jnep.13(2).02010

PACS numbers: 72.80.Tm, 81.05.Qk

\section{INTRODUCTION}

Aluminum is used in industrial application due to its properties like light weight, high electric conductivity and corrosion resistance [1]. Aluminium is used in structural applications due to excellent strength to weight ratio [2]. The addition of ceramic particles improves corrosion, wear and strength resistance [3]. The aluminium composites can be manufactured using various methods.

Stir casting method is widely used to develop composites due to its low cost, simplicity and high production rate [4]. Many researchers have used stir casting for the fabrication of the composites [5]. Khare et al. [68], investigated the effect of $\mathrm{B}_{4} \mathrm{C}, \mathrm{Al}_{2} \mathrm{O}_{3}$ and carbon black reinforcement on mechanical and tribological properties of $\mathrm{Al} 7075$ composites. Kok and Ozdin [9] investigated the effect $\mathrm{Al}_{2} \mathrm{O}_{3}$ particles content and their size on wear behavior of Al 2024 alloy composite. Surappa et al. [10] investigated the effect of $\mathrm{Al}_{2} \mathrm{O}_{3}$ particles on wear behavior of hypereutectic Al-Si alloy.

In recent years to save time and materials mathematical models are becoming effective way to get desired results. In this research, Levenberg-Marquardt Algorithm (LMA) is applied and the results of predictive, experimental and validation are presented. Koksal [11] used ANN to predict mechanical properties in magnesia based refractory materials. The results concluded that ANN can be successfully used to predict the mechanical properties of magnesia based refractory materials with little error. Gupta et al. [12] predicted the mechanical properties of rubberized concrete exposed to elevated temperature using ANN. They observed that ANN can be used to predict the durability properties of rubberized concrete exposed to elevated temperature. Jokhio et al. [13] predicted the mechanical and wear properties of aluminium composite produced using stir casting. The results shows that ANN prediction was reasonable accurate with error percentage within range of $2-7 \%$ in training testing and validation.

\section{EXPERIMENTAL PROCEDURE}

\subsection{Materials and Methods}

The material used in this study is $\mathrm{Al} 7075$ cast composites reinforced with $\mathrm{Al}_{2} \mathrm{O}_{3}$ and $\mathrm{B} 4 \mathrm{C}$ particulates having reinforcement percentage $12 \%$ and $3 \%$ selected from our previous works $[6,7]$ The schematic diagram for stir casting is shown in Fig. 1. The composites are cut into pieces of $1 \mathrm{~kg}$ approximately and placed in crucible of stir casting furnace. The ingots are allowed to heat at a temperature ranging from 700 to $1000{ }^{\circ} \mathrm{C}$.

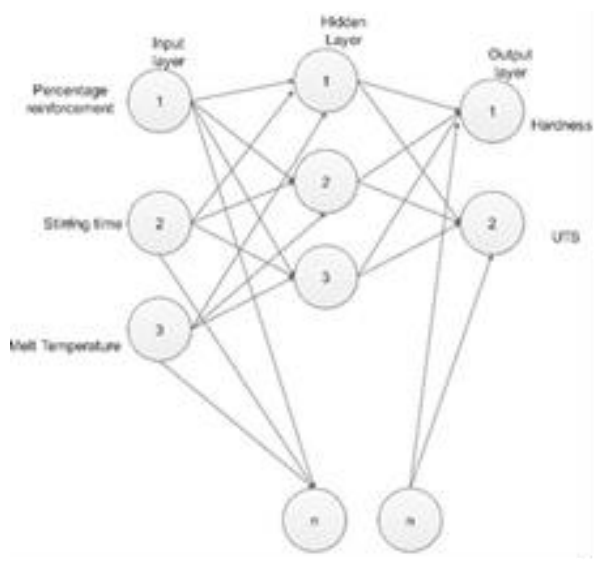

Fig. 1 - ANN model

The preheated reinforcement at about $300{ }^{\circ} \mathrm{C}$ is added to the melt. The melt is then stirred at varying time ranging from 18 to 28 minutes for uniform dispersion of the reinforcement. After stirring, the melt is poured into the preheated dies having temperature range from $180{ }^{\circ} \mathrm{C}$ to $280^{\circ} \mathrm{C}$ and allowed to solidify. The reinforcement carbon is added in varying percentage 5 , 10 and 15 wt. \%. The metal is taken out from the dies and are cut in the desired shapes for testing. 


\subsection{Experimental Design}

The experiments for the present research work are designed using full factorial design which confirms that every possible combination of the various factors and their levels is analyzed. The factors with their levels are shown in Table 1. The experimental plan for the present study in shown in Table 2.

Table 1 - Stir casting factors and their levels

\begin{tabular}{|l|l|l|l|}
\hline Percentage Reinforcement (\%) & 3 & 6 & 9 \\
\hline Stirring Time & 18 & 23 & 28 \\
\hline Molten Metal Temperature & 650 & 700 & 750 \\
\hline
\end{tabular}

Table 2 - Experimental lLayout using 33 (L 27) full factorial design

\begin{tabular}{|l|l|l|l|l|l|}
\hline S.no & $\begin{array}{l}\text { Rein- } \\
\text { force- } \\
\text { ment }\end{array}$ & $\begin{array}{l}\text { Stir- } \\
\text { ring } \\
\text { Time }\end{array}$ & $\begin{array}{l}\text { Molten } \\
\text { Temp }\end{array}$ & $\begin{array}{l}\text { Hard- } \\
\text { ness }\end{array}$ & UTS \\
\hline & $\%)$ & $($ min) & $\left({ }^{\circ}\right.$ C) & $(\mathrm{BHN})$ & $(\mathrm{MPa})$ \\
\hline 1 & 3 & 18 & 650 & 138 & 248 \\
\hline 2 & 3 & 18 & 650 & 139 & 262 \\
\hline 3 & 3 & 18 & 650 & 141 & 262 \\
\hline 4 & 3 & 23 & 650 & 143 & 255 \\
\hline 5 & 3 & 23 & 700 & 145 & 265 \\
\hline 6 & 3 & 23 & 700 & 149 & 253 \\
\hline 7 & 3 & 28 & 750 & 139 & 235 \\
\hline 8 & 3 & 28 & 750 & 138 & 254 \\
\hline 9 & 3 & 28 & 750 & 140 & 278 \\
\hline 10 & 6 & 18 & 700 & 148 & 281 \\
\hline 11 & 6 & 18 & 700 & 151 & 285 \\
\hline 12 & 6 & 18 & 700 & 149 & 274 \\
\hline 13 & 6 & 23 & 750 & 147 & 280 \\
\hline 14 & 6 & 23 & 750 & 149 & 289 \\
\hline 15 & 6 & 23 & 750 & 151 & 270 \\
\hline 16 & 6 & 28 & 650 & 154 & 261 \\
\hline 17 & 6 & 28 & 650 & 153 & 287 \\
\hline 18 & 6 & 28 & 650 & 158 & 274 \\
\hline 19 & 6 & 18 & 750 & 154 & 294 \\
\hline 20 & 9 & 18 & 750 & 152 & 295 \\
\hline 21 & 9 & 18 & 750 & 159 & 282 \\
\hline 22 & 9 & 23 & 650 & 153 & 297 \\
\hline 23 & 9 & 23 & 650 & 152 & 301 \\
\hline 24 & 9 & 23 & 650 & 158 & 283 \\
\hline 25 & 9 & 28 & 700 & 159 & 281 \\
\hline 26 & 9 & 28 & 700 & 154 & 288 \\
\hline 27 & 9 & 28 & 700 & 151 & 282 \\
\hline & & & & & \\
\hline
\end{tabular}

\subsection{Hardness and Tensile Test}

The hardness tests were conducted on Brinell hardness testing matching. Cast samples were in cut in rectangular pieces of $50 \mathrm{~mm} \times 50 \mathrm{~mm}$. The hardness of the composite is taken three times at different points and the average hardness is reported. Tensile Test are conducted on a Universal testing machine. From the tensile test UTS and yield strength for all the specimens were taken. The specimen are cut according to ASTM standard. The test was conducted at room temperature.

\subsection{Predictive Modelling}

To increase the efficiency and reduce production cost predictive modelling is essential for the product development. In this experiment ANN model was developed to predict all the responses. Since ANN networks are effective and convenient to fit non-linear experimental data [14]. In this experiment LevenbergMarquardt Algorithm (LMA) algorithm is used for prediction since it is fastest back-propagation algorithm for training and prediction [14]. The back propagation network is multilayer network consists of three layers the input layer, the hidden layer $(s)$ and the output layer. The network thus consists of three input neurons, three output neurons. To determine the hidden neurons several structures with different number of neurons are considered for best configuration [15].

\subsection{Designing Training and Testing of Neural Network}

The three stir casting parameters which have significant effect on output parameters were taken as input parameters in ANN model and hardness, ultimate tensile strength and yield strength are taken as output parameters. The data for training and testing is obtained from the 27 experiments conducted as per the design of experiments. From a total of 27 experiments 18 experiments (two third) are selected for training and 9 experiments (one third) for testing. The schematic diagram of the ANN model is shown in Fig. 1. The experimental and predicted results were plotted as shown in Fig. 2 and Fig. 3.

\section{RESULTS AND DISCUSSION}

In present work mechanical properties of carbon reinforced $\mathrm{Al}_{2} \mathrm{O}_{3}$ and $\mathrm{B}_{4} \mathrm{C}$ rein- forced composites fabricated using stir casting were studied and predicted using back propagation neural network. The prediction of the mechanical properties was performed for tensile strength and hardness. A close relation is recorded between testing and validation from the modelling results as shown in Fig. 4 .The effect of process variables on mechanical properties of the composites is discussed below.

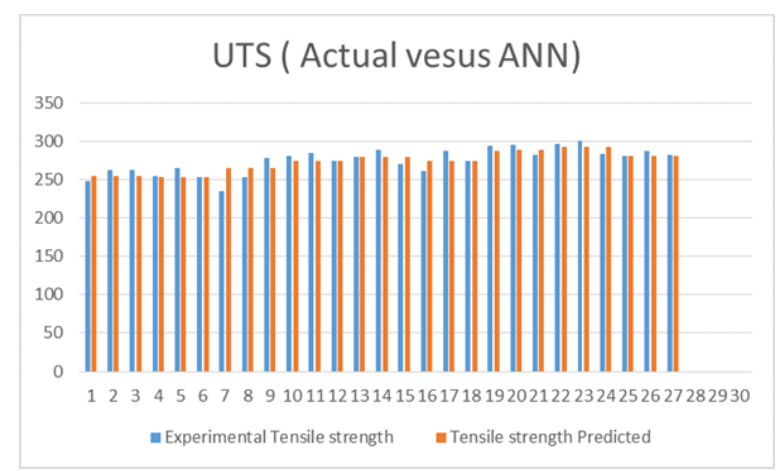

Fig. 2 -Actual versus ANN predicted results for UTS

\subsection{Effect of Percentage Reinforcement on Mechanical Properties of the Composite}

The increase in carbon percentage resulted in the increase in the increase in tensile and hardness of the 
composite. This can be attributed to de-agglomeration. and fine distribution of the reinforcement resulted in the increase in density and fine mechanical properties of the composites.

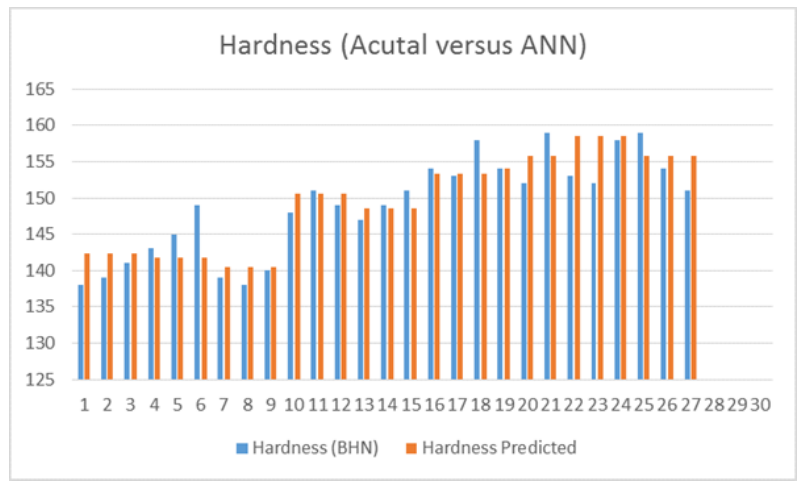

Fig. 3 - Actual versus ANN predicted results for hardness

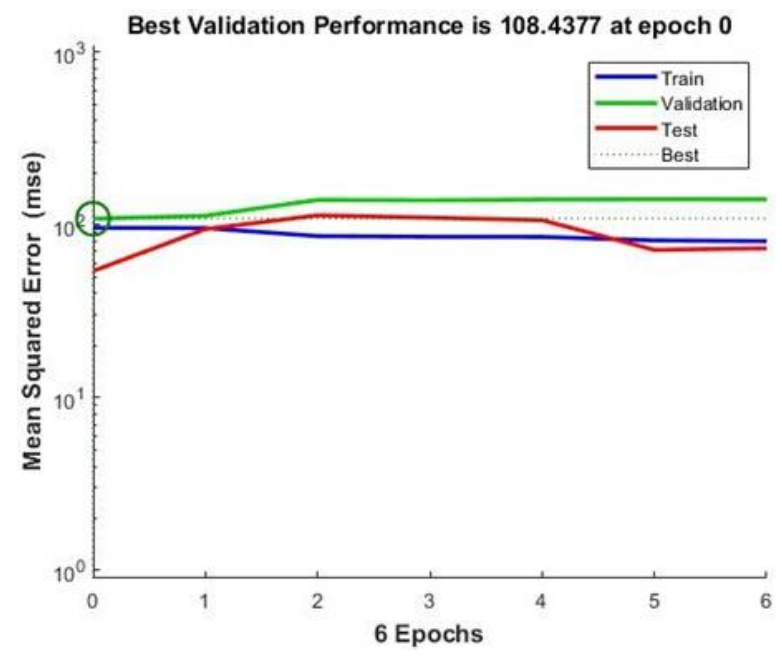

Fig. 4 - Testing, training and validation of the model

\section{REFERENCES}

1. I. Estrada-Guel, C. Carreñ-Gallardo, D.C. Mendoza-Ruiz, M. Miki-Yoshida, E. Rocha-Rangel, R. Mart'inez-S'anchez, J. Alloys Compd. 483 No 1-2, 173 (2009).

2. F. Tang, I.E. Anderson, T. Gnaupel-Herold, H. Prask, Mater. Sci. Eng. A 383 No 2, 362 (2004).

3. B. Torres, M. Lieblich, J. Ib'añez, A. Garcı'ea-Escorial, Scripta Mater. 47 No 1, 45 (2002).

4. R. Jamaati, S. Amirkhanlou, M.R. Toroghinejad, B. Niroumand, Mater. Charact. 62 No 12, 1228 (2011).

5. R. Singh, M. Shadab, A. Dash, R.N. Rai, J. Brazilian Soc. Mech. Sci. Eng. 41 No 2, 98 (2019).

6. Manu Khare, Ravi Kant Gupta, Bhuvnesh Bhardwaj, $S A E$ Int. J. Mat. Manuf. 13 No 3, 372 (2020).

7. Manu Khare, Ravi Kant Gupta, and Bhuvnesh Bhardwaj, Mater. Res. Express 6 No 12, 126512 (2019).

8. Manu Khare, R.K. Gupta, S.S. Ghosh, Mater. Res. Express 6, $126512(2019)$

\subsection{Effect of Stirring time on Mechanical Properties of the Composite}

There is slight variation in the mechanical properties of the composite due to change in the stirring time this might be due to reduction in the density of with further formation of the Journal web-version and data transfer to the abstract databases, which index our Journal sample caused by more porosity absorption due to reinforcement incorporation. Similar behavior is observed by [16].

\subsection{Effect of Melt Temperature on Mechanical Properties of the Composite}

The melt temperature has significantly affected the properties of the casting. The variation in melt temperature has changed the UTS and hardness of the composites as shown in Table 4.

\section{CONCLUSIONS}

- In this study stir casting is used for fabrication of carbon reinforced $\mathrm{Al} 7075 / \mathrm{Al}_{2} \mathrm{O}_{3} / \mathrm{B}_{4} \mathrm{C}$ metal composite. The mechanical properties viz. UTS and hardness are evaluated on the experimental data. ANN model has been developed based on LMA - neural network algorithm to predict these properties. $85 \%$ of these data is used for training and $15 \%$ of the data is used or testing.

- The architecture of the model is LMA with back propagation. The model after successful training can be used to predict various mechanical properties like elongation and abrasive wear resistance of the composites.

- Predictive modelling using ANN is in good agreement with experimental results using training, testing and validation. Using the present model for composite design will reduce large experimental work and cost by optimizing the process parameters.

9. M. Ko"k, K. O“zdin, J. Mater. Proc. Technol. 183 No 2-3, 301 (2007).

10. M.K. Surappa, S.V. Prasad, P.K. Rohatgi, Wear 77 No 3, 295 (1982).

11. N. Sinan Koksal, Computat. Mater. Sci. 47 No 1, 86 (2009).

12. Trilok Gupta, K.A. Patel, Salman Siddique, Ravi K. Sharma, Sandeep Chaudhary, Measurement 147, 106870 (2019).

13. Muhammad Hayat Jokhio, Muhammad Ibrahim Panhwer, Mukhtiar Ali Unar, arXiv:1605.09691 (2016).

14. Hamid Khayyam, Minoo Naebe, Omid Zabihi, Reza Zamani, Stephen Atkiss, Bronwyn Fox, IEEE Trans. Ind. Inform. 11 No 4, 887 (2015).

15. S. Sivasankaran, R. Narayanasamy, T. Ramesh, M. Prabhakar, Computat. Mater. Sci. 47 No 1, 46 (2009).

16. Mohammad Raei, Masoud Panjepour, Mahmood Meratian, Russ. J. Non-Ferr. Met. 57 No 4, 347 (2016). 


\title{
Вплив параметрів процесу лиття з перемішуванням на механічні властивості алюмініевих матричних композитів: експериментальне дослідження та прогностичне моделювання
}

\author{
Manu Khare, Ravi Kant Gupta
}

Manipal University Jaipur, Jaipur, Rajasthan, India

\begin{abstract}
$\mathrm{y}$ роботі штучна нейронна мережа (ANN) використовуеться для моделювання складної природи композитів, які мають нелінійну залежність від параметрів процесів, що впливають на їх властивості. Експерименти проводили з різними контрольованими вхідними параметрами, такими як температура плавлення, відсоток армування та температура штампа, і вивчали їх вплив на механічні характеристики алюмініевих матричних композитів, виготовлених за допомогою лиття з перемішуванням. Для прогнозування властивостей композитів застосовували алгоритм Левенберга-Марквардта. Робота підтверджуе, що нейронна мережа у поеднанні з алгоритмом Левенберга-Марквардта є надійним методом з високим рівнем точності для прогнозування механічних властивостей композитів, виготовлених за допомогою лиття з перемішуванням.
\end{abstract}

Ключові слова: Композиційні матеріали, Керамічне армування, $\mathrm{Al}_{2} \mathrm{O}_{3}, \mathrm{~B}_{4} \mathrm{C}$, Чорний вуглець, $\mathrm{ANN}$ Математичне моделювання. 